\title{
20. OXYGEN-ISOTOPE CONSTRAINTS ON SERPENTINIZATION PROCESSES IN ULTRAMAFIC ROCKS FROM THE MID-ATLANTIC RIDGE $\left(2^{\circ} \mathrm{N}\right)^{1}$
}

\author{
Pierre Agrinier ${ }^{2}$ and Mathilde Cannat ${ }^{3}$
}

\begin{abstract}
Extensively serpentinized peridotites, drilled at the Mid-Atlantic Ridge south of the Kane Fracture Zone (Ocean Drilling Program Holes $920 \mathrm{~B}, 920 \mathrm{D}$, and $670 \mathrm{~A}$ ), have been analyzed for the ${ }^{18} \mathrm{O} /{ }^{16} \mathrm{O}$ ratios of their serpentine and magnetite to derive temperature and water:rock ratio information about the hydrothermal process that produced their serpentinization.

These peridotites have low $\delta^{18} \mathrm{O}$ values $(3.7 \%-2.6 \%)$, and show low ${ }^{18} \mathrm{O} /{ }^{16} \mathrm{O}$ fractionation factors between coexisting serpentine and magnetite; $\Delta$ (serpentine-magnetite) values are between $5.1 \%$ and $3.8 \%$. By applying the serpentine-magnetite geothermometer of Wenner and Taylor (1971) as revised by Früh-Green et al. (1996), we calculate serpentinization temperatures ranging between $430^{\circ}$ and $590^{\circ} \mathrm{C}$. However, a sensitivity analysis shows that large errors affect these temperatures (about $\pm 100^{\circ} \mathrm{C}$ ). Nevertheless, we think we can determine that the serpentinization occurred at temperatures higher than $350^{\circ} \mathrm{C}$.

Using the mass-balance equation developed by Taylor $(1977)$, and assuming that seawater $\left(\delta^{18} \mathrm{O}=0 \%\right.$ ) or ${ }^{18} \mathrm{O}$ hydrothermally enriched seawater $\left(\delta^{18} \mathrm{O}=+2.4 \%\right.$ ) is the serpentinizing fluid, we can determine that the water:rock ratios (in oxygen atom proportions) were, at $400^{\circ} \mathrm{C}$, around $0.55 \pm 0.1$ and $1.05 \pm 0.2$, respectively, and at $500^{\circ} \mathrm{C}, 0.4 \pm 0.1$ and $0.8 \pm 0.1$, respectively.

The relatively high serpentinization temperatures derived from this study imply that serpentinization has occurred at significant depth in the axial lithosphere. This has potentially important consequences, which we discuss, on the amount of tectonic rotation during the uplift of the ultramafic rocks to the seafloor, on the orientation of principal stresses at depth beneath the axial valley, and on the seismic velocity and density structure of the oceanic lithosphere.

All types of serpentine (meshwork and vein) from Site 920 appear to have formed at these relatively high temperatures. However, previous oxygen-isotope studies (Komor et al., 1990; Hébert et al., 1990) of cores from Site 670 reported ultramafic rocks that were serpentinized at lower temperature $\left(<200^{\circ} \mathrm{C}\right)$. This indicates that the ultramafic component of the axial lithosphere in the area did not become entirely serpentinized at depths corresponding to rock temperatures of at least $350^{\circ} \mathrm{C}$.
\end{abstract}

\section{INTRODUCTION}

Serpentinized peridotites are commonly recovered on the seafloor, close to ridge axes, and are examined mostly for their primary phases (olivine, pyroxenes, spinel, plagioclase), allowing high-temperature magmatic and deformational processes to be studied. Records of these early processes are overprinted by serpentinization products, which commonly dominate the mineral phases in oceanic peridotites. Alteration of olivine and pyroxenes into serpentine minerals can, therefore, be seen as a nuisance. From this perspective, serpentinization, however, is worth studying because major physical and chemical properties of the oceanic lithosphere are conditioned by the extent of serpentinization of its ultramafic component. Serpentinization produces large density decreases in ultramafic rocks, which essentially result from volumetric expansion (Nicolas, 1969; Komor et al., 1985; O'Hanley, 1992), and it affects seismic velocities (Christensen, 1972). The rheology of serpentine is also different from that of unserpentinized peridotite, and probably favors strain localization (Raleigh and Paterson, 1965; Escartin et al., 1994). Magnetic properties are also drastically affected by the serpentinization process (Johnson, 1979) because serpentinization produces significant amounts of magnetite. Finally, serpentinization is a major water-consuming alteration process and, therefore, probably affects the chemical budget of mantle/seawater exchanges.

'Karson, J.A., Cannat, M., Miller, D.J., and Elthon, D. (Eds.), 1997. Proc. ODP, Sci Results, 153: College Station, TX (Ocean Drilling Program).

2Laboratoire de Géochimie des Isotopes Stables, Institut de Physique du Globe, 2 place Jussieu, 75251 Paris cedex 05, France. piag@ ccr.jussieu.fr

${ }^{3}$ Laboratoire de Pétrologie, CNRS-URA 736, Université Pierre et Marie Curie, 4 place Jussieu, 75252 Paris cedex 05, France.
In this paper, we report ${ }^{18} \mathrm{O} /{ }^{16} \mathrm{O}$ isotopic data from serpentinized peridotites cored at Sites 670 and 920 in the Mid-Atlantic Ridge south of the Kane Fracture Zone (Fig. 1). Using the oxygen-isotope fractionation factor between coexisting serpentine and magnetite, we derive constraints on serpentinization temperatures. Using oxygenatom balance, we also provide constraints on water:rock ratios during serpentinization, and on the oxygen-isotope composition of the serpentinizing fluid. The detailed mineralogy of serpentinization products in the framework of the isotopic data presented here will be presented in a future paper (Stamoudi et al., 1995). Some mineralogic informations are also available in Dilek, Coulton, et al. (this volume).

\section{SITE LOCATION AND PREVIOUS WORK}

The set of serpentinized peridotite samples studied comes from two Ocean Drilling Program (ODP) sites located in the western axial valley wall of the Mid-Atlantic Ridge (Fig. 1). A single hole, Hole 670A, was drilled at Site 670 during ODP Leg 109 (Shipboard Scientific Party, 1988). Four holes were drilled at Site 920 during Leg 153 (Shipboard Scientific Party, 1995), and the samples selected come from the two deepest ones (Holes 920B and 920D), which are separated by only $18 \mathrm{~m}$ (Table 1). The distance between Sites 670 and 920 is about $20 \mathrm{~km}$. These two sites have been drilled in the same extensive outcrop of serpentinized peridotites (Karson et al., 1987; Mével et al., 1991). These serpentinized peridotites are interpreted as residual mantle material that has been unroofed by extensional tectonics, and extensively altered in the process.

Oxygen-isotope compositions of serpentine from nine serpentinized samples cored at Site 670 were measured previously by Komor et al. (1990) and Hébert et al. (1990). They reported dominantly high 


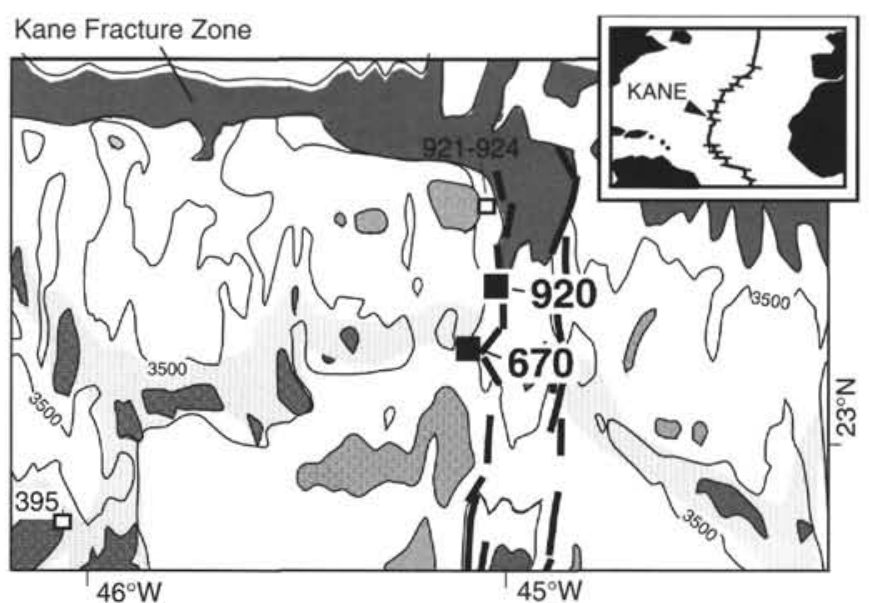

Figure 1. Simplified bathymetric map of the MARK area (after Gente et al., 1991) showing the locations of Sites 395 (Deep Sea Drilling Project Leg 45; serpentinized peridotites and gabbro), 670 (Leg 109), 920 (this study), and 921-924 (Leg 153; gabbros). Bathymetric contours: $4000 \mathrm{~m}$ (domains deeper than $4000 \mathrm{~m}$ in dark gray), $3500 \mathrm{~m}$, and $2500 \mathrm{~m}$ (domains shallower than $2500 \mathrm{~m}$ in lighter gray). Heavy lines show the median valley main scarps. Alignments of basins, interpreted as marking the off-axis trace of axial discontinuities, are outlined in an intermediate shade of gray.

Table 1. Location and drilling record, Holes 670A, 920B, and $920 \mathrm{D}$.

\begin{tabular}{ccccrc}
\hline Hole & $\begin{array}{c}\text { Latitude } \\
(\mathrm{N})\end{array}$ & $\begin{array}{c}\text { Longitude } \\
(\mathrm{W})\end{array}$ & $\begin{array}{c}\text { Depth } \\
(\mathrm{mbsl})\end{array}$ & $\begin{array}{c}\text { Cored } \\
(\mathrm{mbs})\end{array}$ & $\begin{array}{c}\text { Recovered } \\
(\mathrm{m})\end{array}$ \\
\hline $670 \mathrm{~A}$ & $23^{\circ} 09.99^{\prime}$ & $45^{\circ} 01.93^{\prime}$ & 3625 & 92.5 & 6.5 \\
$920 \mathrm{~B}$ & $23^{\circ} 20.31^{\prime}$ & $45^{\circ} 01.04^{\prime}$ & 3328 & 126.4 & 47.8 \\
$920 \mathrm{D}$ & $23^{\circ} 20.32^{\prime}$ & $45^{\circ} 01.04^{\prime}$ & 3327 & 200.8 & 95.1 \\
\hline
\end{tabular}

Notes: $\mathrm{mbsl}=$ meter below sea level, $\mathrm{mbs} f=$ meter below seafloor .

$\delta^{18} \mathrm{O}$ values (up to $8.8 \%$ ), with a wide range of variation and relatively low values $(3.7 \% 0-4.8 \%$ ) in three samples. They calculated serpentinization temperatures of $110^{\circ}$ to $385^{\circ} \mathrm{C}$, assuming oxygen-isotope equilibrium with a hydrothermal fluid having $\delta^{18} \mathrm{O}=+2.4 \%$. The hydrothermal fluid venting at $350^{\circ} \mathrm{C}$ in the Snake Pit vent field has the same isotope composition (Campbell et al.,1988), a few kilometers to the east of Site 920 (Fig. 1). Looking at the core from Site 670 , it appeared to us that some of the most extensively serpentinized intervals had not been included in the sample set analyzed by Komor et al. (1990) and Hébert et al. (1990). We therefore selected two samples of this extensively serpentinized material and added them to our sample set from Site 920 (Table 2).

\section{SERPENTINIZATION TEXTURES AND MINERALOGY}

\section{Site 920}

Serpentinized peridotites cored at Site 920 are $70 \%$ to $100 \%$ serpentinized, relatively coarse-grained harzburgites (Fig. 2A; Shipboard Scientific Party, 1995). In most samples, serpentinization produces arrays of thin serpentine-filled tension cracks, which commonly create an anastomosing foliation in the core (Fig. 2A). These cracks isolate elongated lenses of serpentinized peridotite (Fig. 2B), characterized by a fine-grained mesh of serpentine and magnetite that formed after olivine, and commonly less-serpentinized aggregates of orthopyroxene, containing interstitial clinopyroxene and olivine. Orthopyroxene in these lenses is partially altered to bastite pseudomorphs. Clinopyroxene is commonly fresh. When altered, it turns into bastite, with minor amounts of acicular amphibole. The finegrained, mesh-textured serpentine + magnetite after olivine locally includes minute olivine relics, and is commonly anisotropic, with a honeycomb texture elongated subparallel to the thicker serpentine tension cracks in the sample. The density and degree of preferred orientation of these macroscopic cracks are variable in the core, but samples completely free of such cracks (Fig. 2A) are uncommon (Shipboard Scientific Party, 1995). Reorientation of the core using paleomagnetic measurements has shown that these cracks are dominantly north-south trending, and have an easterly dip, subparallel to the slope of the axial valley wall (Shipboard Scientific Party, 1995).

The core from Site 920 also contains some crosscutting veins of pale-green serpentine (Fig. 2C; Table 1), and other, later veins of a smectite-carbonate mesh (not included in this study).

Serpentine, in mesh and veins, is composed of lizardite + chrysotile (Dilek, Coulton, et al., this volume; Stamoudi et al., 1995); in addition, significant amounts of antigorite have also been identified by a transmission electron microscopy study (Stamoudi et al., 1995).

\section{Site 670}

Serpentinization textures in the ultramafic rocks cored at Site 670 are heterogeneous. Orange to pale-green serpentinized harzburgites with a well-defined spinel and orthopyroxene foliation are the volumetrically dominant group of samples (Shipboard Scientific Party, 1988). All but one of the samples analyzed in the Komor et al. (1990) oxygen-isotope study belong to that group (the one exception is a dark-green serpentinite and has the lowest $\delta^{18} \mathrm{O}$ values). According to Komor et al. (1990), the serpentine assemblage is composed of chrysotile + lizardite \pm antigorite \pm talc). The core also contains intervals of $100 \%$ serpentinized material, characterized by a distinctive tortoiseshell texture (Fig. 3), and a probable dunitic protolith (Shipboard Scientific Party, 1988). The two samples analyzed in this paper come from this type of interval.

\section{OXYGEN-ISOTOPE COMPOSITION OF SERPENTINE AND MAGNETITE}

\section{Analytical Method}

The serpentine and the magnetite were separated and purified using hand-picking, hand-held magnet, Frantz magnetic separator and heavy liquid techniques. After $4 \mathrm{hr}$ drying at $150^{\circ} \mathrm{C}$ under vacuum, oxygen was extracted from serpentine using bromine pentafluoride at $600^{\circ} \mathrm{C}$ (Clayton and Mayeda, 1963) and reacted with carbon to produce $\mathrm{CO}_{2}$. Then $\mathrm{CO}_{2}$ was introduced into a Finnigan Mat Delta E mass spectrometer to determine its ${ }^{18} \mathrm{O} /{ }^{16} \mathrm{O}$ (reported in $\delta^{18} \mathrm{O}$ vs. SMOW, \%o unit). Analytical reproducibilities were about $0.2 \%$ ( $\sigma)$, and the mean oxygen yield from serpentines was $16.03 \mu \mathrm{mol} / \mathrm{mg} \pm$ $0.9(\sigma, \mathrm{n}=22)$. During the spring of 1995 , the mean $\delta^{18} \mathrm{O}$ value of NBS 28 standard was $9.46 \pm 0.12 \% \circ(\sigma, n=6)$.

Oxygen was extracted from magnetite grains $(\approx 1 \mathrm{mg})$ by laser fluorination (Sharp, 1990). After cryogenic and $\mathrm{KBr}$ purifications, the liberated oxygen was frozen onto a 100-mg, 13X, molecular sieve at liquid nitrogen temperature (Clayton and Mayeda, 1983). Oxygen was then selectively released by heating the sieve to $-140^{\circ} \mathrm{C}$, and finally trapped onto a 5- $\AA$ molecular sieve at liquid nitrogen temperature for a precise yield measurement. Careful monitoring of the completion of the oxygen trapping prevented any isotopic fractionation during these procedures. The mean oxygen yield from magnetites was $8.85 \mu$ moles $/ \mathrm{mg} \pm 0.4(\sigma, \mathrm{n}=15)$. During the spring of 1995 , the mean $\delta^{18} \mathrm{O}$ value of a therzolitic olivine standard was $5.3 \pm 0.18 \%$ o $(\sigma$, $\mathrm{n}=7)$, and the mean $\delta^{18} \mathrm{O}$ value of a fused quartz standard was 11.3 $\pm 0.25 \%(\sigma, \mathrm{n}=4)$, in contrast to $11.2 \pm 0.16 \% \circ(\sigma, \mathrm{n}=12)$ obtained by the conventional fluorination method.

The isotopic fractionation between two phases A and B is defined as

$$
\Delta(\mathrm{A}-\mathrm{B})=\delta^{18} \mathrm{O}_{\mathrm{A}}-\delta^{18} \mathrm{O}_{\mathrm{B}} \approx 1000 \ln (\alpha[\mathrm{A}-\mathrm{B}]) .
$$


Table 2. Petrography and texture of serpentinized peridotites.

\begin{tabular}{|c|c|c|}
\hline Sample number & Type & $\begin{array}{l}\text { Depth } \\
\text { (mbsf) }\end{array}$ \\
\hline \multicolumn{3}{|l|}{ 153-920B- } \\
\hline 3R-1 (Piece 8, 115-120 cm) & $\begin{array}{l}\text { Serpentinized pyroxene-rich harzburgite with serpentine mesh after olivine and orthopyroxene and } \\
\text { some green amphibole after clinopyroxene. } 90 \% \text { to } 100 \% \text { altered. }\end{array}$ & $27.0 \pm 0.7$ \\
\hline 6R-1 (Piece 8, 74-83 cm) & $\begin{array}{l}\text { Serpentinized harzburgite with serpentine replacing olivine and bastite replacing orthopyroxene } \\
\text { cut by one altered pyroxenitic vein and by a late, carbonate-rich vein. } 90 \% \text { to } 100 \% \text { altered. }\end{array}$ & $53.7 \pm 0.4$ \\
\hline 12R-5 (Piece 1B, 59-65 cm) & $\begin{array}{l}\text { Serpentinized harzburgite with crosscutting serpentine vein. Serpentine replaces olivine and } \\
\text { orthopyroxene. } 95 \% \text { to } 100 \% \text { altered. }\end{array}$ & $115.2 \pm 0.2$ \\
\hline 13R-1 (Piece 2E, $82-88 \mathrm{~cm}$ ) & $\begin{array}{l}\text { Serpentinized lherzolite with serpentine mesh replacing olivine and orthopyroxene, minor } \\
\text { amphibole replacing pyroxenes. Highly to pervasively altered }(75 \%-90 \%) \text {. }\end{array}$ & $118.3 \pm 0.2$ \\
\hline \multicolumn{3}{|l|}{ 153-920D- } \\
\hline 8R-2 (Piece 6B, 124-128 cm) & $\begin{array}{l}\text { Serpentinized harzburgite with serpentine mesh replacing olivine and orthopyroxene. Cut by late } \\
\text { carbonate-rich vein. Highly to pervasively altered }(75 \%-90 \%) \text {. }\end{array}$ & $67.1 \pm 0.3$ \\
\hline 16R-1 (Piece 1B, 14-20 cm) & $\begin{array}{l}\text { Serpentinized harzburgite with serpentine mesh replacing olivine and pyroxenes. Minor amphibole } \\
\text { replaces pyroxene; } 1 \text {-cm-wide crosscutting serpentine vein. Highly to pervasively altered ( } 75 \%- \\
90 \%) \text {. }\end{array}$ & $133.6 \pm 0.1$ \\
\hline $22 \mathrm{R}-4$ (Piece $1 \mathrm{~A}, 11-16 \mathrm{~cm}$ ) & $\begin{array}{l}\text { Serpentinized harzburgite with serpentine mesh replacing olivine and pyroxenes. Highly to } \\
\text { pervasively altered }(75 \%-90 \%) \text {. }\end{array}$ & $194.1 \pm 0.2$ \\
\hline \multicolumn{3}{|l|}{$109-670 \mathrm{~A}-$} \\
\hline $5 \mathrm{R}-1(135-139 \mathrm{~cm})$ & Extensively (100\%) serpentinized (dunite?) with tortoiseshell texture. & -45.3 \\
\hline $5 R-2(0-4 \mathrm{~cm})$ & Extensively $(100 \%)$ serpentinized (dunite?) with tortoiseshell texture. & $\sim 46.0$ \\
\hline
\end{tabular}

Notes: Values listed in "Depth" column are the mean and standard deviation of Euler's Beta distribution (see explanations in Agrinier and Agrinier, 1994).

\section{Results}

The oxygen-isotope ratios for the serpentines in Leg 153 and Leg 109 serpentinized peridotites are given in Table 3 . All the serpentines are strongly depleted in ${ }^{18} \mathrm{O}\left(\delta^{18} \mathrm{O}\right.$ between $2.5 \%$ and $4.1 \%$, compared with the $\delta^{18} \mathrm{O}$ of fresh peridotitic olivine and pyroxene (between 5\%o and 6\%o; Taylor, 1968; Javoy, 1970, 1980). Because oxygen is the principal constituent of silicate minerals in peridotites, such a large decrease of the initial $\delta^{18} \mathrm{O}$ values necessarily requires the supply of large quantities of hydrothermal fluids during serpentinization. Such high water:rock ratio conditions were shown to be generally met for continental serpentinizing systems (Barnes and O'Neil, 1969) and for other oceanic serpentinized peridotites (Kimball and Gerlach, 1986). Late veins of serpentine that crosscut mesh serpentines have $\delta^{18} \mathrm{O}$ values in a narrow range $(2.8 \% o-2.5 \%$ o $)$. This interval overlaps the lower range of the $\delta^{18} \mathrm{O}$ values from the mesh serpentine interval.

Sample 153-920D-16R-1 (Piece 1B, 14-20 cm) is the only sample we studied that contains bastite replacing orthopyroxene with a $\delta^{18} \mathrm{O}$ composition of $5.3 \%$, similar to that of the orthopyroxene precursor. The preservation of high $\delta^{18} \mathrm{O}$ compositions in this sample suggests that serpentinization of the orthopyroxene occurred at a low water:rock ratio $(<0.1$ in atomic proportion). In the analyzed samples where bastite replacing orthopyroxene coexists with serpentine after olivine, the $\delta^{18} \mathrm{O}$ values of bastite are either higher (Samples 153920D-16R-1, Piece 1B, 14-20 cm; and 153-920B-13R-1, Piece 2E, 82-88 cm), or similar (Samples 153-920B-3R-1, Piece 8, 115-120 cm; 153-920B-12R-5, Piece 1B, 59-65 cm; 109-670A-5R-1, 135$139 \mathrm{~cm}$ ) to those the serpentine after olivine.

\section{Oxygen-Isotope Fractionation Between Serpentine and Magnetite}

The $\delta^{18} \mathrm{O}$ compositions in coexisting magnetite and serpentine after olivine in six serpentinized peridotite samples were measured: three from Hole 920B, one from Hole 920D, and two from Hole $670 \mathrm{~A}$. In all these samples, $\delta^{18} \mathrm{O}$ compositions of magnetite and of serpentine are homogenous $(-1.4 \pm 0.3 \%)$ and $(3.1 \pm 0.4 \% o)$, respectively. It is worth noting that the observed dispersions of the $\delta^{18} \mathrm{O}$ compositions for serpentine and magnetite are comparable to the analytical reproducibilities $(0.4 \%$ and $0.3 \%$ vs. $0.2 \%$ ) , therefore indicating that, most likely, the compositions of magnetite and of serpentine are homogenous.This homogeneity of the $\delta^{18} \mathrm{O}$ values suggests that serpentine and magnetite were all formed during the same alteration event.

The corresponding oxygen-isotope fractionations, $\Delta^{18}$ (serpentinemagnetite), are small (between $5.1 \%$ and $3.8 \%$ ), and are lower than the previously published values for oceanic serpentinized peridotites (above 9.5\%o; Wenner and Taylor, 1973) but are similar to those measured in Hess Deep serpentinized peridotites (Früh-Green et al., 1996; Agrinier et al., 1995). Although the ${ }^{18} \mathrm{O}$ fractionation between serpentine and magnetite has not yet been calibrated vs. temperature by laboratory experiments, some natural observations and regularities have led Wenner and Taylor (1971) to propose the following "tentative" geothermometer (revised by Früh-Green et al., 1996):

$$
1000 \ln (\alpha[\text { serpentine-magnetite }])=1.81\left(10^{6} / \mathrm{T}^{2}\right)+1.41
$$

This geothermometer has also been "calibrated" by theoretical calculations (Zheng and Simon, 1991; Zheng, 1993), which, however, provide a different equation. Nonetheless, this work confirms that the serpentine-magnetite geothermometer follows the normal trend expected from the usual behavior of the fractionation of the oxygen isotopes between silicate and oxide minerals (i.e., low-temperature fractionation yields high $\Delta$ (serpentine-magnetite) and high-temperature fractionation yields low $\Delta$ (serpentine-magnetite); Urey, 1947). Using this empirical geothermometer for the $\Delta$ (serpentine-magnetite) values measured in the samples from Sites 670 and 920, we obtain minimum serpentinization temperatures of $430^{\circ} \mathrm{C}$ and maximum temperatures of $590^{\circ} \mathrm{C}$. Nevertheless, considerable uncertainties $\left( \pm 120^{\circ} \mathrm{C}\right.$, at least $)$ are associated with these temperatures. These uncertainties are caused by the poor sensitivity of the serpentine-magnetite geothermometer in the high-temperature range (see Javoy, 1977 ) and also by our poor knowledge of the true relationship between $\Delta$ (serpentine-magnetite) and temperature. At this current state of knowledge, we think that these temperatures, which are all above $350^{\circ} \mathrm{C}$, indicate that serpentinization of the samples we have analyzed occurred at high temperatures (i.e., $>350^{\circ} \mathrm{C}$ ). Most of the oxygen-isotope studies of oceanic serpentinized peridotites to date have suggested lower temperatures of serpentinization $\left(70^{\circ}-250^{\circ} \mathrm{C}\right.$; Wenner and Taylor, 1971; Sheppard, 1980; Bonatti et al., 1984). However, high temperatures of serpentinization, similar to those calculated in this paper, have recently been reported from the Hess Deep ultramafic exposures (East Pacific Rise; Agrinier et al., 1995; Früh-Green et al., 1996).

\section{Water-Rock Interaction Parameters During Serpentinization}

The oxygen-isotope composition of the serpentinizing fluid and the water:rock ratio during serpentinization can be constrained using the approach developed by Taylor (1977). He showed that, during 


\section{A}

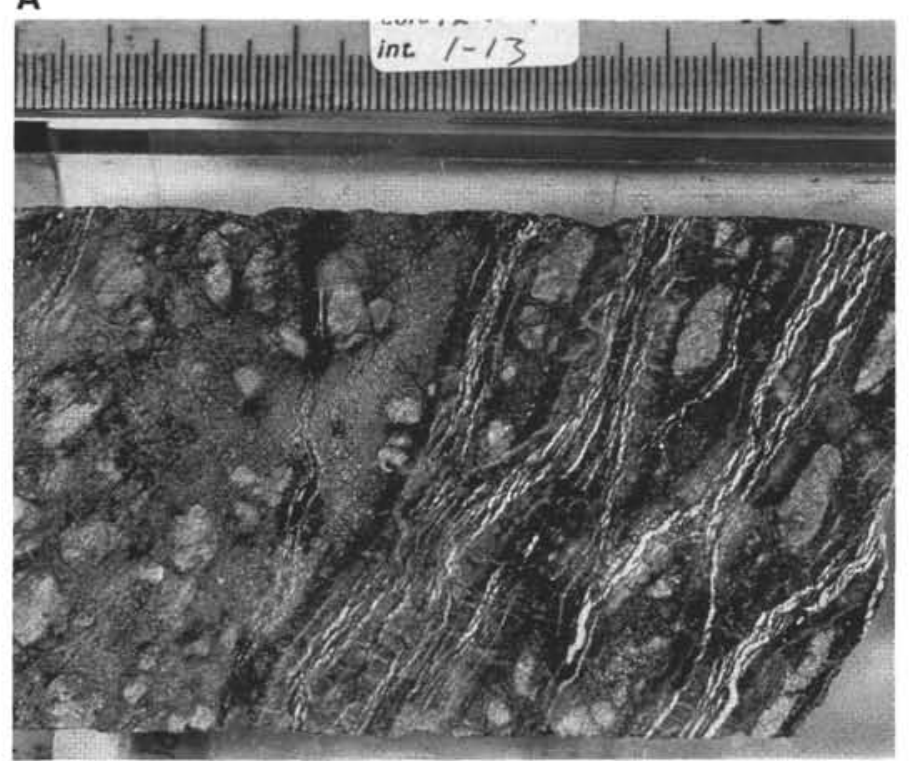

B

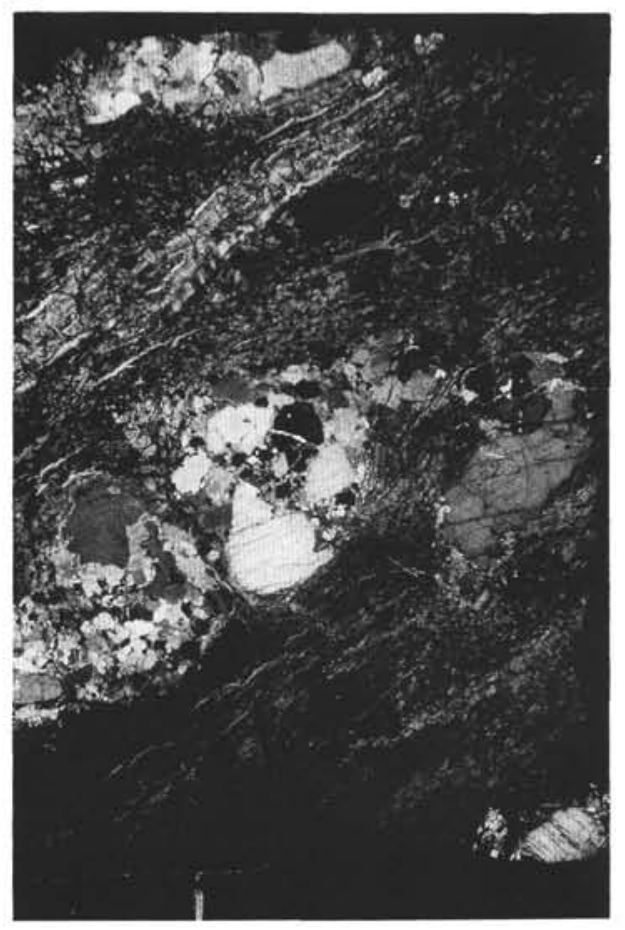

C

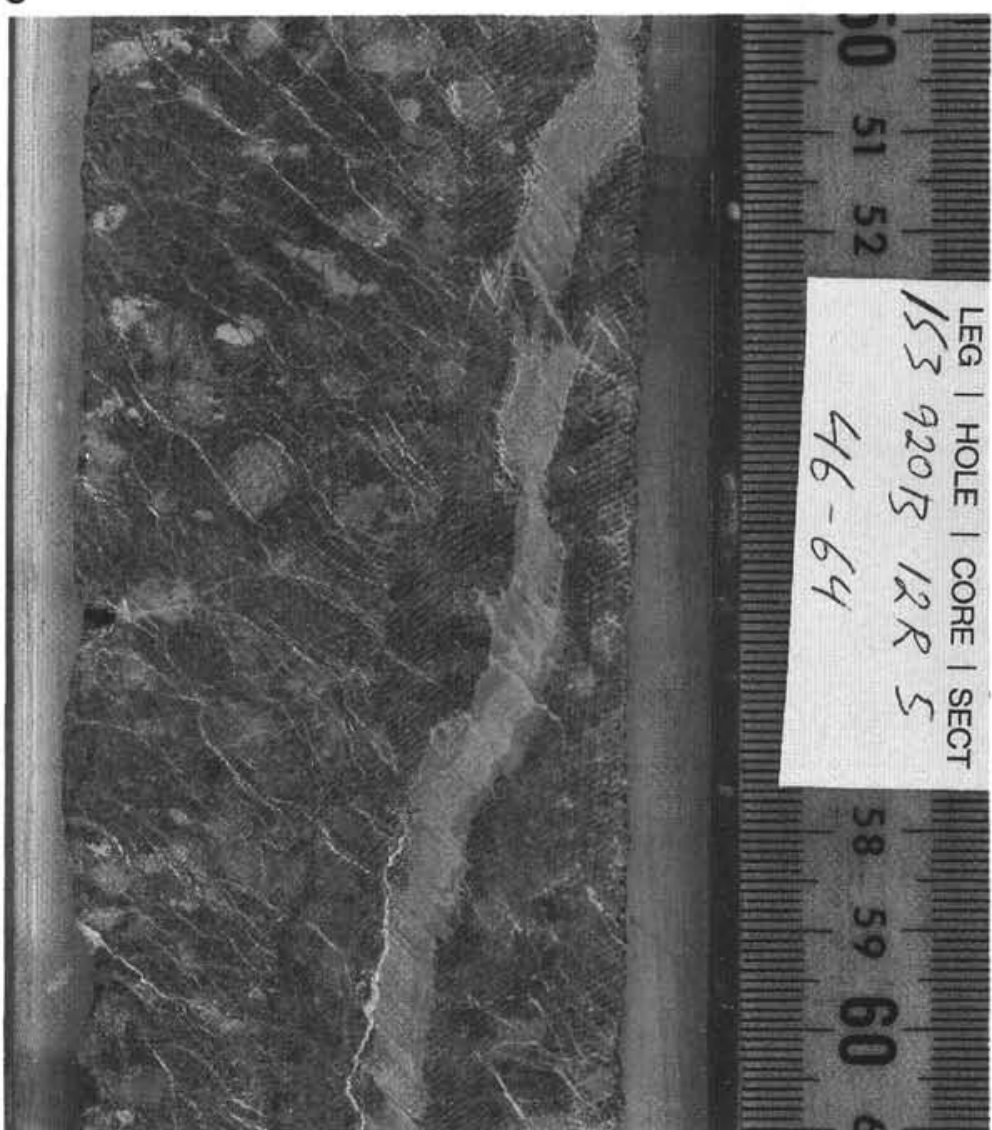

Figure 2. Serpentinized peridotites cored at Site 920. A. Sample 153-920D-12R-1 (Piece 1, 3-11 cm). Typical texture of serpentinized harzburgite at Site 920, with anastomosing serpentine tension cracks, light-colored, moderately serpentinized pyroxene and olivine aggregates in a darker matrix of serpentinized olivine. Length of view is $2 \mathrm{~cm}$. B. Photomicrograph, Sample 153-920D-15R-4 (Piece 1, 27-30 cm), showing detail of moderately serpentinized pyroxene and olivine aggregates in a darker matrix of serpentinized olivine, cut by anastomosing serpentine tension cracks. C. Sample 153-920B-12R-5 (Piece 1B, 50-61 cm). Crosscutting serpentine vein in serpentinized harzburgite with anastomosing serpentine tension cracks (oxygen-isotope compositions for this sample are listed in Table 2). 

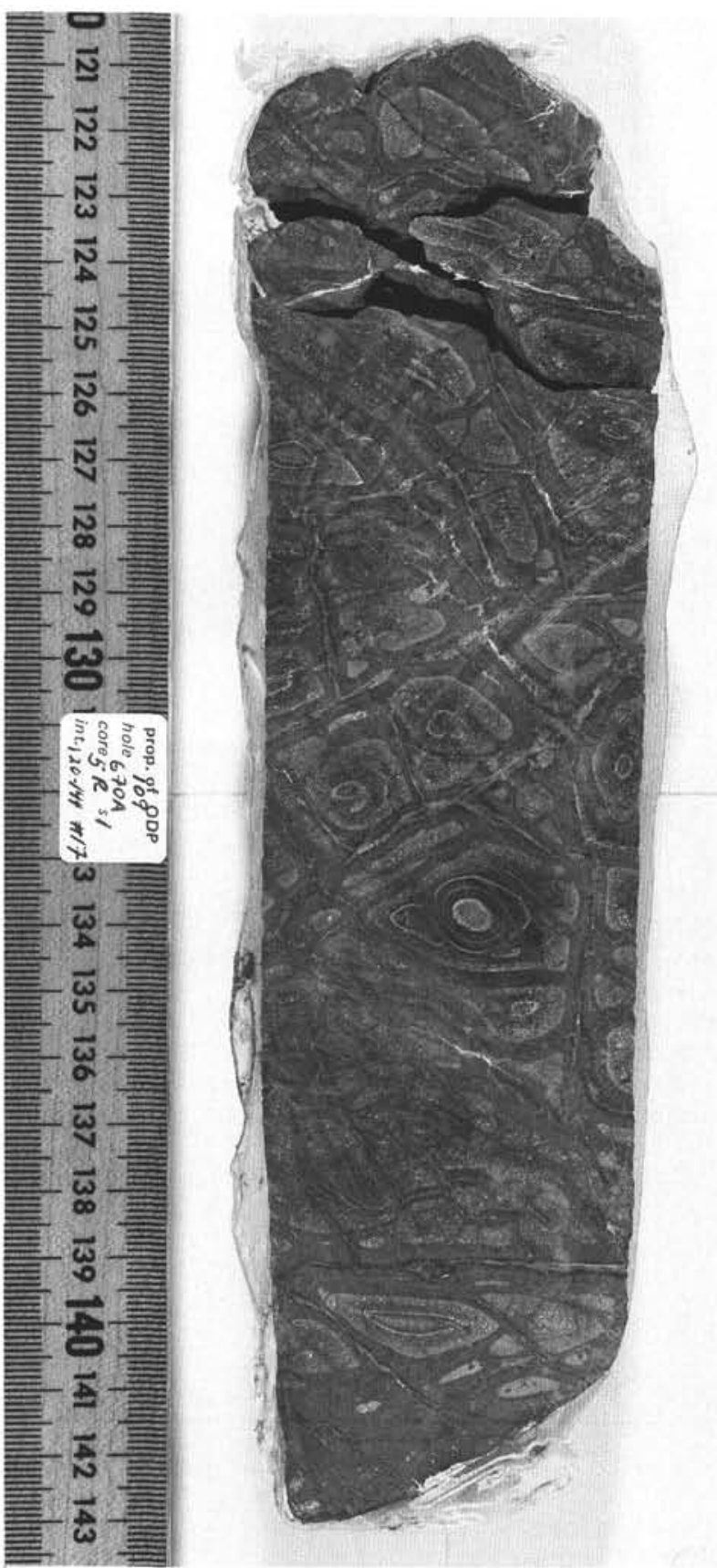

Figure 3. Tortoiseshell texture in serpentinite from Site 670. Sample 109670A-5R-1 (Piece 17, 125-147 cm). Serpentinization appears to have proceeded in concentric rims, from a set of crosscutting fractures. The absence of bastites after orthopyroxene suggests that the protolith was probably a dunite.

water-rock interactions, four factors rule the evolution of $\delta^{18} \mathrm{O}$ compositions in the interacting water and in the rock:

1. The temperature that controls the fractionation factors of oxygen;

2. The water:rock ratio, which controls the amplitude of the evolution of the $\delta^{18} \mathrm{O}$ compositions (mass-balance equation written for the oxygen isotopes);

3. The original $\delta^{18} \mathrm{O}$ composition of the rock; and

4. The original $\delta^{18} \mathrm{O}$ composition of the fluid.
The water:rock ratios can be constrained using Taylor's equation and the serpentine-magnetite geothermometer can be used to constrain temperatures. For oceanic peridotites, the third factor is not ambiguous: olivine and pyroxenes consistently have normal $\delta^{18} \mathrm{O}$ mantle values (i.e., 5\%o-6\%o). Factor 4 , however, requires discussion, because the serpentinizing fluid was not necessarily unmodified seawater. It is unlikely, however, that this serpentinizing fluid was of magmatic origin, because basaltic melts are water undersaturated and consequently cannot produce large amounts of magmatic $\mathrm{H}_{2} \mathrm{O}$-rich fluids (Johnson et al., 1994). The $\delta^{18} \mathrm{O}$ composition of the water in equilibrium with serpentines can be calculated, using the oxygen-isotope fractionation factor between serpentine and water proposed by Wenner and Taylor (1971) and revised by Früh-Green et al. (1996):

$$
\begin{aligned}
& \delta^{18} \mathrm{O}_{\text {water final }}=\delta^{18} \mathrm{O}_{\text {serpentine }}-\Delta(\text { serpentine-water }), \\
& \text { where } \Delta(\text { serpentine-water }) \approx 1.51\left(10^{6} / \mathrm{T}^{2}\right)-4.57
\end{aligned}
$$

At a temperature of $400^{\circ} \mathrm{C}, \Delta$ (serpentine-water) is about $-1.2 \%$. Using this equation, we calculate fluid compositions $\left(\delta^{18} \mathrm{O}_{\text {water final }}\right)$ that ranges between $3.3 \%$ and $4.4 \% \circ$ at $350{ }^{\circ} \mathrm{C}$. This range is shifted to higher values ( $4.3 \%$ o to $5.4 \%$ ) at $450^{\circ} \mathrm{C}$. Again, a considerable uncertainty ( $\pm 1 \%$ at least) is associated with these values because the temperature calibration of the $\Delta$ (serpentine-water) factor is not well known (Früh-Green et al., 1996).

Using these $\delta^{18} \mathrm{O}_{\text {water final }}$ values, water:rock ratios during serpentinization can be calculated by applying Taylor's mass-balance relationship (1977):

$$
\frac{\mathrm{W}}{\mathrm{R}}=\frac{\delta^{18} \mathrm{O}_{\text {serpentine }}-\delta^{18} \mathrm{O}_{\text {olivine }}}{\delta^{18} \mathrm{O}_{\text {serpentinized fluid }}-\delta^{18} \mathrm{O}_{\text {water final }}}
$$

Figure 4 shows the calculated water:rock ratios vs. the $\delta^{18} \mathrm{O}$ composition of the serpentinizing fluid, assuming a serpentinization temperature of $400^{\circ} \mathrm{C}$. At this temperature, all the curves have an infinite tangent (for infinite water:rock ratio) always below $\delta^{18} \mathrm{O}_{\text {serpentinizing fluid }}$ $=4.8 \%$ o. This fluid composition is the upper limit for the serpentinizing fluid. At $500^{\circ} \mathrm{C}$, it is shifted to $5.4 \%$. These upper limits rule out high $\delta^{18} \mathrm{O}_{\text {serpentinizing fluid }}$ fluids ( $>6 \%$ ) such as "magmatic water"; they cannot produce the observed ${ }^{18} \mathrm{O}$-depleted sepentines at such high temperatures. These two upper limits allow seawater $(0 \%)$ or a seawater-derived fluid $(2.4 \%$, like the hydrothermal fluids sampled at Snake Pit vent field by Campbell et al., 1988), to have been the serpentinizing fluids. At $400^{\circ} \mathrm{C}$, the corresponding water:rock ratios (in oxygen atom proportions) are $0.55 \pm 0.1$ and $1.05 \pm 0.2$, respectively, being lowered to $0.4 \pm 0.1$ and $0.8 \pm 0.1$ if serpentinization occurred at $500^{\circ} \mathrm{C}$.

\section{DISCUSSION AND CONCLUSION}

\section{Homogeneity of Oxygen-Isotope Compositions in Serpentinites}

The set of serpentine samples studied in this paper has homogenous $\delta^{18} \mathrm{O}$ compositions $(3.1 \pm 0.4 \%, \sigma$; Table 3$)$. Because there is a causal dependence between the $\delta^{18} \mathrm{O}_{\text {serpentine }}$ and the conditions of serpentinization, this homogeneity could reflect, to some degree, homogeneity of serpentinization conditions. We would expect fluctuations of the values of the parameters that control serpentinization, such as temperature, water:rock ratio, and $\delta^{18} \mathrm{O}_{\text {serpentinizing fluid, }}$ to produce variations of the $\delta^{18} \mathrm{O}_{\text {serpentine }}$. However, the amplitude of these variations should reflect the sensitivity of $\delta^{18} \mathrm{O}_{\text {serpentine }}$ to each parameter. As we will show now, this sensitivity is quite variable.

A sensitivity analysis of thermometric Equations 1 and 2 shows that significant variations in serpentinization temperature at low tem- 
Table 3. Oxygen-isotope composition of serpentinized peridotites.

\begin{tabular}{|c|c|c|c|}
\hline Sample number & Type & $\delta^{18} \mathrm{O}$ & $\Delta$ (serpentine-magnetite) \\
\hline \multirow{4}{*}{$\begin{array}{l}\text { 153-920B- } \\
\text { 3R-1 (Piece 8, 115-120 cm) }\end{array}$} & & & \\
\hline & $\begin{array}{l}\text { Bastite replacing orthopyroxene } \\
\text { Serpentine after olivine }\end{array}$ & $\begin{array}{l}2.6 \\
2.8\end{array}$ & \\
\hline & Magnetite & -1.2 & 4.0 \\
\hline & Black serpentine mesh & 2.6 & \\
\hline \multirow[t]{2}{*}{ 6R-1 (Piece 8, 74-83 cm) } & Black serpentine mesh & 2.8 & \\
\hline & Late serpentine vein & 2.7 & \\
\hline \multirow[t]{5}{*}{ 12R-5 (Piece 1B, 59-65 cm) } & Bastite replacing orthopyroxene & 3.3 & \\
\hline & Serpentine after olivine & 3.5 & \\
\hline & Magnetite & -1.6 & 5.1 \\
\hline & Black serpentine mesh & 2.6 & \\
\hline & Late serpentine vein & 2.5 & \\
\hline \multirow[t]{4}{*}{ 13R-1 (Piece 2E, 82-88 cm) } & Bastite replacing orthopyroxene & 4.1 & \\
\hline & Serpentine after olivine & 2.8 & \\
\hline & Magnetite & -1.9 & 4.7 \\
\hline & Black serpentine mesh & 2.6 & \\
\hline \multicolumn{4}{|l|}{ 153-920D- } \\
\hline 8R-2 (Piece 6B, 124-128 cm) & Serpentine mesh & 3.3 & \\
\hline \multirow[t]{4}{*}{$16 \mathrm{R}-1$ (Piece 1B, 14-20 cm) } & Bastite replacing orthopyroxene & 5.3 & \\
\hline & Serpentine & 3.7 & \\
\hline & Black serpentine mesh & 4.5 & \\
\hline & $\begin{array}{l}\text { Translucent serpentine at vein } \\
\text { margin }\end{array}$ & 2.8 & \\
\hline \multirow{2}{*}{ 22R-4 (Piece 1A, 11-16 cm) } & Serpentine after olivine & 3.5 & \\
\hline & Magnetite & -1.0 & 4.5 \\
\hline \multirow{4}{*}{$\begin{array}{l}109-670 \mathrm{~A}- \\
5 \mathrm{R}-1(135-139 \mathrm{~cm})\end{array}$} & & & \\
\hline & Bastite replacing orthopyroxene & 2.6 & \\
\hline & Serpentine after olivine & 2.6 & \\
\hline & $\begin{array}{l}\text { Magnetite } \\
\text { Black serpentine mesh }\end{array}$ & $\begin{array}{r}-1.3 \\
2.8\end{array}$ & 3.9 \\
\hline \multirow[t]{2}{*}{$5 \mathrm{R}-2(0-4 \mathrm{~cm})$} & Serpentine after olivine & 3.2 & \\
\hline & Magnetite & -1.6 & 3.8 \\
\hline
\end{tabular}

\section{Water-rock ratio} (oxygen atomic proportion)

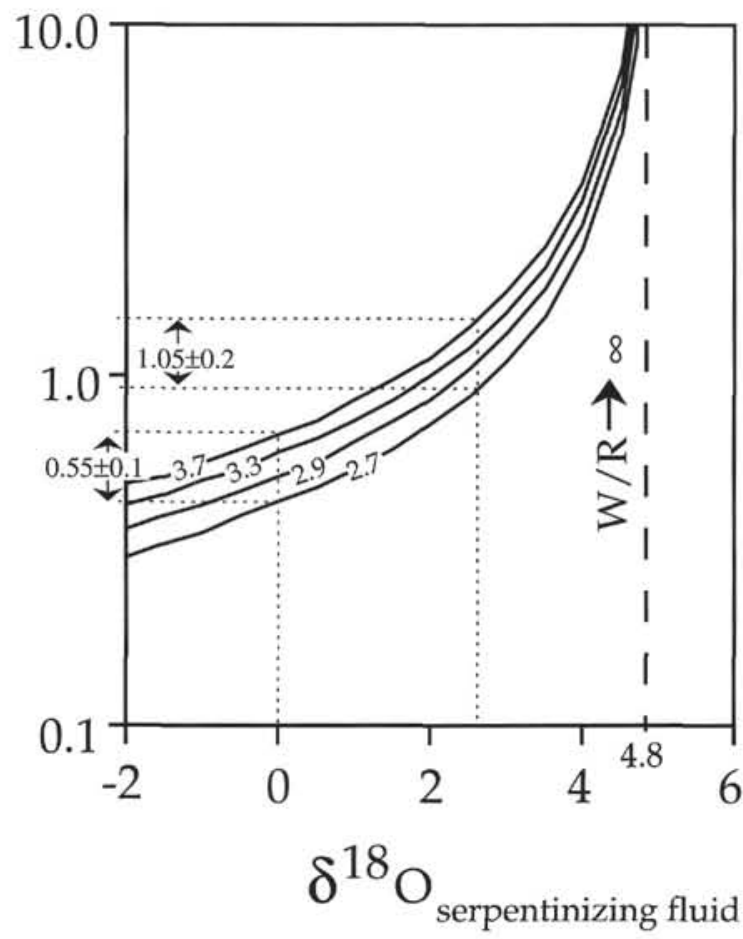

Figure 4. Plot of $\delta^{18} \mathrm{O}_{\text {serpentinizing fluid }}$ vs. water:rock ratio (oxygen atomic proportion). Curves are calculated using the mass-balance equation (Eq. 3) of Taylor (1977), and $\delta^{18} \mathrm{O}_{\text {final water }}$ calculated using Equation 2 for a temperature of $400^{\circ} \mathrm{C}$. Labels on the curves are the $\delta^{18} \mathrm{O}_{\text {serpentine. }}$ All the curves have an infinite tangent $(\mathrm{W} / \mathrm{R} \rightarrow \infty)$ for $\delta^{18} \mathrm{O}_{\text {serpentinizing fluid }}=4.8 \%$. The dotted lines give the range of water:rock ratios for two serpentinized fluids: seawater $\left(\delta^{18} \mathrm{O}_{\text {serpentinizing fluid }}=0 \%\right.$ ) and hydrothermally enriched seawater $\left(\delta^{18} \mathrm{O}_{\text {serpentinizing fluid }}=2.4 \%\right)$. perature $\left(<250^{\circ} \mathrm{C}\right)$ should produce large changes of $\delta^{18} \mathrm{O}_{\text {serpentine }}$, because the oxygen-isotope fractionation factor between serpentine and water is linearly related to the inverse of the square of the temperature (see Eqs. 1, 2). In contrast, as discussed above, the serpentinizationtemperature dependence of $\delta^{18} \mathrm{O}_{\text {serpentine }}$ is weak for temperatures higher than $350^{\circ} \mathrm{C}$. This shows that the homogeneity of $\delta^{18} \mathrm{O}_{\text {serpentine }}$ measured in our samples is not necessarily an indication that serpentinization occurred within a narrow range of temperatures.

For the water:rock ratio (Eq. 3) and the $\delta^{18} \mathrm{O}_{\text {serpentinizing fuid, the sen- }}$ sitivity analysis is more complicated because these two parameters are negatively coupled (see curves in Fig. 4). For a given $\delta^{18} \mathrm{O}_{\text {serpentine, }}$, any increase in the water:rock ratio may be balanced by a decrease in the $\delta^{18} \mathrm{O}_{\text {serpentinizing fluid. }}$ An infinite set of coupled water:rock ratios and $\delta^{18} \mathrm{O}_{\text {serpentinizing fluid }}$ values may therefore produce the same $\delta^{18} \mathrm{O}_{\text {serpentine, }}$, but this coupling is not linear. At low water:rock ratios $(<1.0$ in oxygen atomic proportion), the curves have a shallow slope, and large changes in $\delta^{18} \mathrm{O}_{\text {serpentinizing fuid }}$ are balanced by small changes in the water:rock ratio (displayed using log units in Fig. 4). The opposite is true at high water:rock ratios ( $>1$ in oxygen atomic proportion), where the curves are nearly vertical. If we assume that the serpentinizing fluid is seawater or hydrothermally enriched seawater $\left(\delta^{18} \mathrm{O}_{\text {serpentinizing fluid }}=\right.$ $2.5 \%$ ), we determine that the observed range of $\delta^{18} \mathrm{O}_{\text {serpentine }}$ may actually be caused only by significant variations of the water:rock ratio $(0.55 \pm 0.1$ and $1.05 \pm 0.2)$ at $400^{\circ} \mathrm{C}$, whereas at $500^{\circ} \mathrm{C}$, this range is smaller $(0.4 \pm 0.1$ and $0.8 \pm 0.1$, respectively).

\section{Geodynamic Implications}

Despite the large uncertainties in temperature determinations, it is safe to propose that serpentinization in our sample set occurred at temperatures greater than $350^{\circ} \mathrm{C}$. It was, therefore, not a superficial effect, following the exposure of the ultramafic rocks on the seafloor. In our set of serpentinized ultramafic rocks, the oxygen-isotope results also indicate that serpentinization occurred at high (between 0.3 and 1.25 ), but presumably variable, water:rock ratios, assuming that the serpentinizing fluid was seawater or ${ }^{18} \mathrm{O}$-enriched seawater.

As discussed above, the homogeneity of $\delta^{18} \mathrm{O}$ compositions of all types of analyzed serpentine from Site 920 (serpentine bastites after pyroxene, mesh-textured serpentine after olivine, and late, crosscut- 
ting serpentine veins) is striking (Table 3). This suggests that, although there are variations in the degree of serpentinization and in the development of anastomosing serpentine tension cracks (Fig. 2), all the ultramafic rocks recovered at Site 920 were serpentinized at depths corresponding to a rock temperature of a least $350^{\circ} \mathrm{C}$.

Serpentinization produces significant amounts of magnetite, allowing for a strong remnant magnetism to be acquired. This remnant magnetism, which allowed reorientation of structures measured in the cores, has, within errors, the same inclination and declination as the present-day magnetic field in the area (Shipboard Scientific Party, 1995). This would suggest that the ultramafic rocks sampled at Site 920 have not undergone significant tectonic rotations after serpentinization. Considering that serpentinization occurred at significant depths, this lack of tectonic rotation would imply that the tectonics, which allowed the ultramafic rocks to be unroofed from the depth at which they became serpentinized to their present position in the seafloor, were not accompanied by much block tilting.

Serpentinization in the ultramafic rocks cored at Site 920 also included the formation of the east-dipping anastomosing tension cracks that are conspicuous features of the core (Shipboard Scientific Party, 1995). In the absence of late tectonic rotations, the north-south-trending, eastward-dipping preferred orientation of these cracks (Shipboard Scientific Party, 1995) could therefore be analyzed in terms of the orientation of principal deviatoric stresses below the axial domain, at a depth corresponding to a rock temperature of at least $350^{\circ} \mathrm{C}$. It would suggest that the least principal stress at this depth was east-west trending, with a moderate westward dip. Incidentally, this is precisely the type of dip that is predicted for the least principal stress by Phipps Morgan et al. (1987) in a model for the formation of the Median Valley.

The high permeability of partially serpentinized peridotite (Macdonald and Fyfe, 1985) makes it plausible that serpentinization in the ultramafic rocks recovered at Site 920 occurred rapidly, as a rather catastrophic event.

If generalized to the ultramafic component of the oceanic lithosphere in the area, such a catastrophic serpentinization event would also have considerable thermal (because of the exothermic nature of serpentinization reactions; Fyfe, 1974), tectonic (because of the large volume increase associated with serpentinization), and magnetic implications (because serpentinized peridotites have magnetic susceptibilities similar to those of basalts). It would also have consequences on the thickness of the oceanic crust, because peridotites that have been serpentinized belong to the crust in terms of their density and seismic velocity (Hess, 1962; Christensen, 1972).

However, the high $\delta^{18} \mathrm{O}_{\text {serpentine }}$ values measured in most ultramafic rocks cored at nearby Site 670 (Komor et al., 1990; Hébert et al., 1990), and in other abyssal ultramafic samples (Wenner and Taylor, 1971; Sheppard, 1980; Bonatti et al., 1984), lead us to curb our enthusiasm. These high $\delta^{18} \mathrm{O}_{\text {serpentine }}$ values, which indicate low temperatures of serpentinization $\left(<200^{\circ} \mathrm{C}\right)$, are evidence that the ultramafic component of the axial lithosphere in the area did not become entirely serpentinized at depths corresponding to rock temperature of at least $350^{\circ} \mathrm{C}$. Only the most extensively serpentinized Site 670 samples yield low $\delta^{18} \mathrm{O}_{\text {serpentine }}$ values. These samples also appear to have a dunitic protolith (Fig. 3), in contrast to the other samples from Site 670, which are harzburgitic. We do not know why they have undergone earlier, higher temperature serpentinization, but it might reflect this initial difference in lithology.

\section{ACKNOWLEDGMENTS}

We are indebted to S.C. Komor, C. Mével, and C. Stamoudi for useful comments and suggestions. We thank Stuart R. Boyd for editing the English of this manuscript. We thank Martine Rodier, Sandra Panzolini, Agnès Michel, Michel Girard, and Jean-Jacques Bourrand for their technical help. We also thank the captain, the crew, and the drilling and the technical staffs of the JOIDES Resolution. Financial support for our work was provided by INSU-CNRS ("Géosciences marines" program).

\section{REFERENCES}

Agrinier, P., and Agrinier, B., 1994. Comment on the knowledge of the depth of a rock sample from a drilled core. Sci. Drilling, 4:259-265.

Agrinier, P., Hékinian, R., Bideau, D., and Javoy, M., 1995. Stable isotope compositions $\left({ }^{18} \mathrm{O} /{ }^{16} \mathrm{O}, \mathrm{D} / \mathrm{H}\right.$, and $\left.{ }^{13} \mathrm{C} /{ }^{12} \mathrm{C}\right)$ of oceanic crust and upper mantle rocks exposed in the Hess Deep near the Galapagos Triple Junction. Earth Planet. Sci. Lett., 136:183-196.

Barnes, I., and O'Neil, J.R., 1969. The relationship between fluids in some fresh Alpine-type ultramafics and possible modern serpentinization, Western United States. Bull. Geol. Soc. Am., 80:1947-1960.

Bonatti, E., Lawrence, J.R., and Morandi, N., 1984. Serpentinization of ocean-floor peridotites: temperature dependence on mineralogy and boron content. Earth Planet. Sci. Lett., 70:88-94.

Campbell, A.C., Palmer, M.R., Klinkhammer, G.P., Bowers, T.S., Edmond, J.M., Lawrence, J.R., Casey, J.F., Thompson, G., Humphris, S., Rona, P.A., and Karson, J.A., 1988. Chemistry of hot springs on the Mid-Atlantic Ridge. Nature, 335:514-519.

Christensen, N.I., 1972. The abundance of serpentinites in the oceanic crust. J. Geol., 80:709-719.

Clayton, R.N., and Mayeda, T.K., 1963. The use of bromine pentafluoride in the extraction of oxygen from oxides and silicates for isotopic analysis. Geochim. Cosmochim. Acta, 27:43-52.

, 1983. Oxygen isotopes in eucrites, shergottites, naklites and chassignites. Earth Planet. Sci. Lett., 62:1-6.

Escartin, J., Hirth, G., and Evans, B., 1994. Experimental constraints on the strength of serpentine: implications for mid-ocean ridge tectonics. Eos, 75:650.

Früh-Green, G.L., Plas, A., and Lécuyer, C., 1996. Petrologic and stable isotope constraints on hydrothermal alteration and serpentinization of the EPR shallow mantle at Hess Deep (Site 895). In Mével, C., Gillis, K.M., Allan, J.F., and Meyer, P.S. (Eds.), Proc. ODP, Sci. Results, 147: College Station, TX (Ocean Drilling Program), 255-291.

Fyfe, W.S., 1974. Heats of chemical reactions and submarine heat production. Geophys. J. R. Astron. Soc., 37:213-215.

Gente, P., Durand, C., Pockalny, R., Maia, M., Deplus, C., Mével, C., Ceuleneer, G., Cannat, M., Laverne, C., Aslanian, D., Campan, A., Léau, H., Marion, E., and Seyler, M., 1994. Oblique structures on the flanks of the Mid-Atlantic Ridge: fossil traces of the along-strike propagation of the accretion segments. C. R. Acad. Sci. Ser. 2, 318:1239-1246.

Hébert, R., Adamson, A.C., and Komor, S.C., 1990. Metamorphic petrology of ODP Leg 109, Hole 670A serpentinized peridotites: serpentinization processes at a slow spreading ridge environment. In Detrick, R., Honnorez, J., Bryan, W.B., Juteau, T., et al., Proc. ODP, Sci. Results, 106/ 109: College Station, TX (Ocean Drilling Program), 103-115.

Hess, H.H., 1962. History of ocean basins. Geol. Soc. Am., Buddington Vol., $599-620$.

Javoy, M., 1970. Utilisation des isotopes de l'oxygéne en magmatologie [Ph.D. thesis]. Univ. of Paris VII, Paris.

, 1977. Stable isotopes and geothermometry. J. Geol. Soc. London, 133:609-636.

, 1980. ${ }^{18} \mathrm{O} /{ }^{16} \mathrm{O}$ and $\mathrm{D} / \mathrm{H}$ ratios in high temperature peridotites. Colloq. Int. C.N.R.S., 272:279-287.

Johnson, H.P., 1979. Magnetization of the oceanic crust. Rev. Geophys. Space Phys., 17:215-226.

Johnson M.C., Anderson, A.T., Jr., and Rutherford, M.J., 1994. Pre-eruptive volatile contents of magmas. Rev. Mineral., 30:281-330.

Karson, J.A., Thompson, G., Humphris, S.E., Edmond, J.M., Bryan, W.B., Brown, J.R., Winters, A.T., Pockalny, R.A., Casey, J.F., Campbell, A.C., Klinkhammer, G., Palmer, M.R., Kinzler, R.J., and Sulanowska, M.M., 1987. Along-axis variations in seafloor spreading in the MARK area. Nature, 328:681-685.

Kimball, K.L., and Gerlach, D.C., 1986. Sr isotopic constraints on hydrothermal alteration of ultramafic rocks in two oceanic fracture zones from the South Atlantic Ocean. Earth Planet. Sci. Lett., 78:177-188.

Komor, S.C., Elthon, D.E., and Casey, J.F., 1985. Serpentinization of cumulate ultramafic rocks from the North Arm Mountain massif of the Bay of Islands ophiolite. Geochim. Cosmochim. Acta, 49:2331-2338.

Komor, S.C., Grove, T.L., and Hébert, R., 1990. Abyssal peridotites from ODP Hole $670 \mathrm{~A}\left(21^{\circ} 10 \mathrm{~N}, 45^{\circ} 02 \mathrm{~W}\right)$ : residues of mantle melting exposed by non-constructive axial divergence. In Detrick, R., Honnorez, 
J., Bryan, W.B., Juteau, T., et al., Proc. ODP, Sci. Results, 106/109: College Station, TX (Ocean Drilling Program), 85-101.

Macdonald, A.H., and Fyfe, W.S., 1985. Rate of serpentinization in seafloor environments. Tectonophysics, 116:123-135.

Mével, C., Cannat, M., Gente, P., Marion, E., Auzende, J.-M., and Karson, J.A., 1991. Emplacement of deep crustal and mantle rocks on the west median valley wall of the MARK area (MAR $23^{\circ} \mathrm{N}$ ). Tectonophysics, 190:31-53.

Nicolas, A., 1969. Serpentinisation d'une Therzolite: bilan chimique, implication tectonique. Bull. Volcanol., 32:499-508.

O'Hanley, D.S., 1992. Solution to the volume problem in serpentinization. Geology, 20:705-708.

Phipps Morgan, J., Parmentier, E.M., and Lin, J., 1987. Mechanisms for the origin of mid-ocean ridge axial topography: implications for the thermal and mechanical structure at accreting plate boundaries. J. Geophys. Res., 92:12823-12836.

Raleigh, C.B., and Paterson, M.S., 1965. Experimental deformation of serpentinite and its tectonic implications. J. Geophys. Res., 70:3965-3985.

Sharp, Z.D., 1990. A laser-based microanalytical method for the in situ determination of oxygen isotope ratios of silicates and oxides. Geochim. Cosmochim. Acta, 54:1353-1357.

Sheppard, S.M.F., 1980. Isotopic evidence for the origins of water during metamorphic processes in oceanic crust and ophiolite complexes. Colloq. Int. C.N.R.S., 272:135-147.

Shipboard Scientific Party, 1988. Site 670. In Bryan, W. B., Juteau, T., et al., Proc. ODP, Init. Repts., 109: College Station, TX (Ocean Drilling Program), 203-238.

, 1995. Site 920. In Cannat, M., Karson, J.A., Miller, D.J., et al., Proc. ODP, Init. Repts., 153: College Station, TX (Ocean Drilling Program), 45-119.
Stamoudi, C., Mével, C., Agrinier, P., and Gaudichet, A., 1995. Nature et signification des phases serpentineuses dans les péridotites océaniques serpentinisées de Hess Deep et MARK. J. Spec. S.G.F., Geosci. Mar. Brest, 66.

Taylor, H.P., Jr., 1968. The oxygen isotope geochemistry of igneous rocks. Contrib. Mineral. Petrol., 19:1-71.

- 1977. Water/rock interactions and the origin of $\mathrm{H}_{2} \mathrm{O}$ in granitic batholiths. J. Geol. Soc. London, 133:509-558.

Urey, H.C., 1947. The thermodynamic properties of isotopic substances. $J$. Chem. Soc., 1947:562-581.

Wenner, D.B., and Taylor, H.P., Jr., 1971. Temperatures of serpentinization of ultramafic rocks based on ${ }^{16} \mathrm{O} /{ }^{18} \mathrm{O}$ fractionation between coexisting serpentine and magnetite. Contrib. Mineral. Petrol., 32:165-185.

1973. Oxygen and hydrogen isotope studies of the serpentinization of ultramafic rocks in oceanic environments and continental ophiolitic complexes. Am. J. Sci., 273:202-239.

Zheng, Y.-F., 1993. Calculation of oxygen isotope fractionation in hydroxylbearing silicates. Earth Planet. Sci. Lett., 120:247-263.

Zheng, Y.-F., and Simon, K., 1991. Oxygen isotope fractionation in hematite and magnetite: a theoretical calculation and application to geothermometry of metamorphic iron-formations. Eur. J. Mineral., 3:877-886.

Date of initial receipt: 7 August 1995

Date of acceptance: 1 February 1996

Ms 153SR-033 